\title{
A ROMAN IMPORTS FROM THE SLAVIC-AGE SETTLEMENT IN CRAIOVA, THE POINT "FÂNTÂNA OBEDEANU"
}

Dorel Bondoc

\section{Un import roman din aşezarea de epocă slavă de la Craiova, punctul "Fântâna Obedeanu"}

Obiectul acestul articol se referă la o tijă de bronz, descoperită în interiorul unei locuințe descoperite într-o săpătură arheologică de salvare în oraşul Craiova, în punctul Fântâna Obedeanu, Săpăturile arheologice au pus în evidență mai multe vestigii, iar dintre acestea cele mai semnificative sunt cele de epocă slavă. Au fost datate larg în secolele V-VI. Este vorba despre patru locuințe semiîngropate, prevăzute fiecare cu câte un cuptor. Inventarul prelevat este destul de sărac şi constă în principal în ceramică, lucrată fie cu mâna, fie la roată.

O piesă similară provine de la Cioroiu Nou (fig. 6-7). Condițiile de descoperire sunt necunoscute; este vorba despre săpături mai vechi făcute de către D. Tudor.

Cele două obiecte descoperite la Craiova şi Cioroiu Nou reprezintă piese de cult aparținând epocii romane târzii. Prezența lor la nord de Dunăre se datorează unor influențe culturale sau ca urmare a schimburilor economice.

$\mathrm{Nu}$ a fost încă lămurită pe deplin utilitatea unor astfel de obiecte. Au fost propuse identificări ale lor drept furci de tors cu verigă pentru deget sau tije purtate de membrii sectei bonosiacilor, dar discuția privind acest subiect rămâne încă deschisă.

Key words: Late Roman Period, Craiova, Cioriu Nou, bronze rod, dove.

In 1975 rescue were conducted in Craiova, at a site called Fântâna Obedeanu, located at the town's western extremity, on the right side of the road that leads towards Drobeta TurnuSeverin ${ }^{1}$. The name of this place comes from a fountain made here several centuries before by the Obedeanu family².

The archaeological excavations lead to many discoveries, among which the most significant were dated to the Slavic period, more precisely the $5^{\text {th }}-6^{\text {th }} \mathrm{c}$. There are four dwellings, each of them with a fireplace. The inventory is poor and it consists mainly of handmade or wheel-thrown pottery.

Among the most remarkable discoveries is a bronze $\operatorname{rod}^{3}$, discovered inside dwelling no. 2 (fig. 2). This object's craftsmanship (fig. 2-5) contrasts highly with the rest of a rather poor inventory, as we have mentioned. On the upper part, on a socle adorned with horizontal, parallel incised lines, a dove is rendered. On the bird's body three little circles were incised, one of which was identified with the dove's eye. Below the socle starts the bronze rod, which has a round cross-section. $5.8 \mathrm{~cm}$ below the socle there is a rectangular prominence $(1 \times 0.5 \mathrm{~cm})$ with a square cross-section $(0.5 \times 0.5 \mathrm{~cm})$ and oblique incised lines. There are 7 further centimeters to the end of the rod, which finishes with a ring (diam. $2.2 \mathrm{~cm}$ ). The object's total length is $19.5 \mathrm{~cm}$ and at the present moment can be found in the Museum of Oltenia, Craiova, inv. I 47529.

\footnotetext{
${ }^{1}$ Popilian, Nica 2005, 148-165.

${ }^{2}$ Vasilescu 1927, 188-192.

${ }^{3}$ Popilian, Nica 2005, 163, pl. VI/5.
} 
It is certainly an imported object, in clear contrast to the poor inventory of the dwellings dated to the Slavic period. The dove could indicate the object's Christian nature and one should notice that south of the Danube many similar artifacts were discovered ${ }^{4}$.

These objects are characteristic to the Late Roman Period and can be dated as late as the $6^{\text {th }} \mathrm{c}$. The first discoveries are dated to the $3^{\text {rd }} \mathrm{c}$., as is indicated by the artifacts uncovered at Romula, which were sharpened at the lower end ${ }^{5}$. It is plausible to conclude that in the Late Roman Period the sharp ends have been replaced by rings.

A similar piece comes from Cioroiu Nou (figs. 6-7). The context of the discovery is unknown (older excavations made by D. Tudor).

Only a fragment of the object was preserved, namely the square prominence $(0.4 \times 0.4$ $\mathrm{cm}$ ) near its middle section. At the end of the object there is a ring (diam. $2.4 \mathrm{~cm}$ ). According to known analogies (see above the piece from Craiova), the piece must have had a dove at the upper part. The preserved length is $10 \mathrm{~cm}$. The artifact is preserved in the Museum of Oltenia, Craiova, inv. I 25178.

The context of the discovery being unknown, its dating could be determined only by analogies and by the latest discoveries from Cioroiu Nou. Thus, inside the area of the fortification, Gh. Popilian discovered a $5^{\text {th }}$ c. grave ${ }^{6}$. The inventory contained just one piece, a belt that can be dated to the middle of the $5^{\text {th }} \mathrm{c}$. according to R. Harhoiu ${ }^{7}$. We have no further archaeological evidence related to the object in question.

In 2000, in the ruins of the Roman baths from the north-western corner of the fortification, we discovered the traces of another grave, destroyed by modern interventions (holes, agricultural works); it contained a fragment of a young man's skull, perhaps a woman (information provided by Mr. Andrei Soficaru). The grave discovered by Gh. Popilian and the skull fragment discovered in 2000 by the author of this paper could suggest that the area of the Roman fortification at Cioroiu Nou was used as a cemetery during the $5^{\text {th }} \mathrm{c}$.

The two objects from Craiova and Cioroiu Nou belong to the Late Roman Period. Their presence north of the Danube can be explained as a cultural influence or as a result of local trade.

The utility of such objects is not clear: they could be distaffs (the ring was used for fixing the device on the finger $)^{8}$, rods worn by adepts of the Bonosian heresy ${ }^{9}$ or something else.

\section{BIBLIOGRAPHY}

Bondoc, Dincă 2003 - D. Bondoc, D.R. Dincă, Tipare şi figurine ceramice romane din centrul ceramic de la Romula. Muzeul Romanațiului Caracal / Roman moulds and figurines of ceramic from the ceramic centre from Romula. The museum from Caracal, Craiova.

Bozu 1993 - O. Bozu, Obiecte creştine inedite de uz casnic. Furcile de tors pentru deget datate in secolele IV-VI e.n., AB, S.N. (Arheologie-istorie) 2, 206-213.

Harhoiu 1997 - R. Harhoiu, Die frühe Völkerwanderungszeit in Rumänien, Bukarest.

Lazarov 2001 - L. Lazarov, Historical museum - Dalgopol. Ancient bronze. Catalog, Varna.

\footnotetext{
${ }^{4}$ For example in Bulgaria, according to Lazarov 2001, nos. 93-98.

${ }^{5}$ Popilian 1976, 243, fig. 13/12-13; Bondoc, Dincă 2003, 41, nos. 33-34.

${ }^{6}$ Toropu 1976, 83.

${ }^{7}$ Harhoiu 1997, pl. CXXXVIII/60.

${ }^{8}$ Bozu 1993, 206-213.

${ }^{9}$ Zugravu 1997, 291 and footnote no. 140.
} 
Madgearu 2008 - Al. Madgearu, A Stick with Dove Head Found at Halmyris, CCDJ, Călăraşi, 24, 221230.

Popilian 1976 - Gh. Popilian, Un quartier artisanal à Romula, Dacia NS 20, 221-250.

Popilian, Nica 2005 - Gh. Popilian, M. Nica, Aşezarea prefeudală de la Craiova (Fântâna Obedeanu), Drobeta $15,148-165$.

Toropu 1976 - O. Toropu, Romanitatea târzie şi străromânii în Dacia traiană sud-carpatică, Craiova.

Vasilescu 1927 - Al. A. Vasilescu, Fântâna Obedeanului în sec. XVIII-lea, AO 6, 29-30, 188-192.

Zugravu 1997 - N. Zugravu, Geneza creştinismului popular al românilor, Bucureşti.

\section{LIST OF FIGURES}

Fig. 1. - House no. 2 at "Fântâna Obedeanu", Craiova.

Fig. 2. - A bronze rod (photo) discovered inside House no. 2.

Fig. 3. - A bronze rod (photo detail) discovered inside House no. 2. 


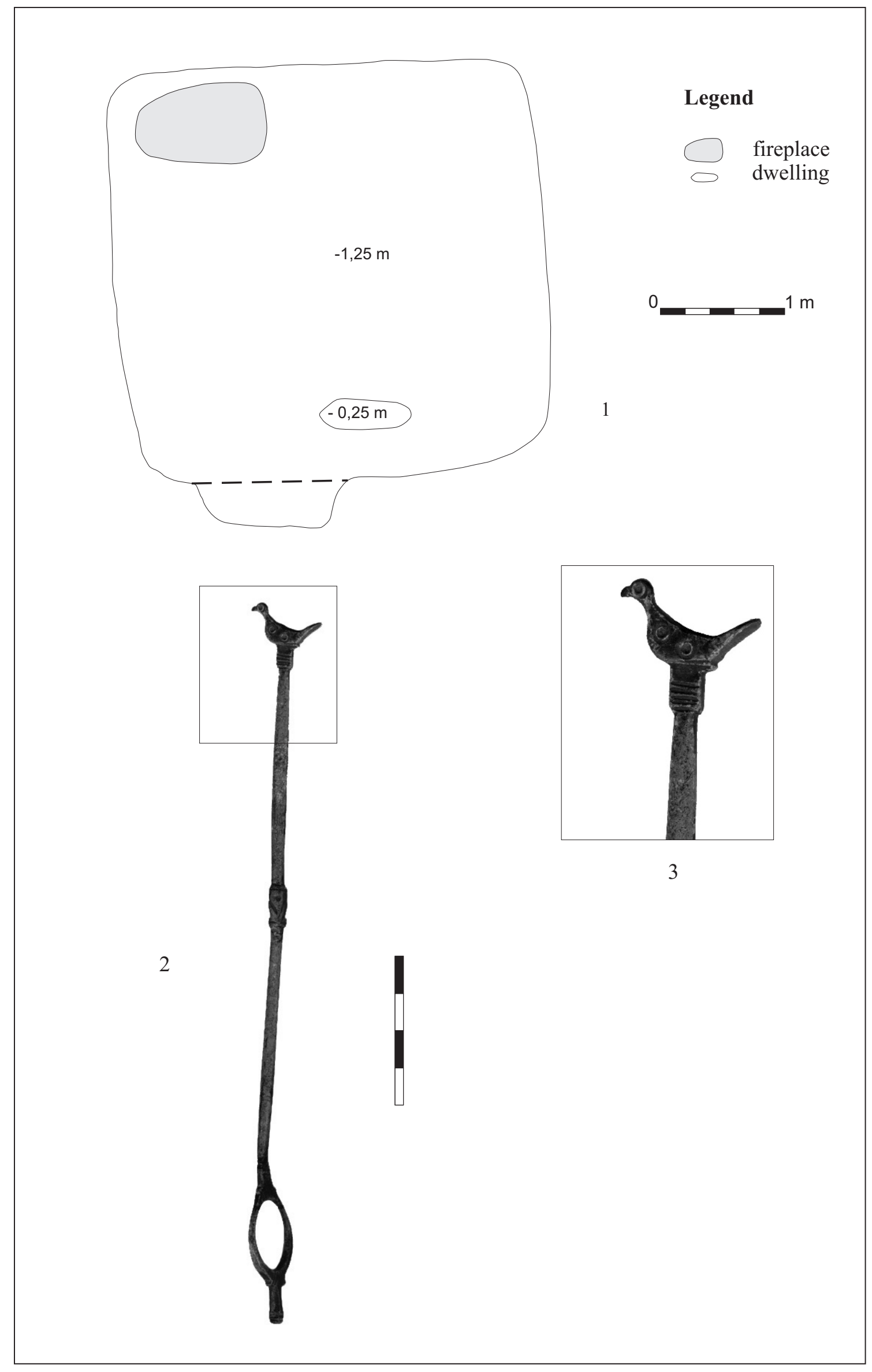

Pl. 1 